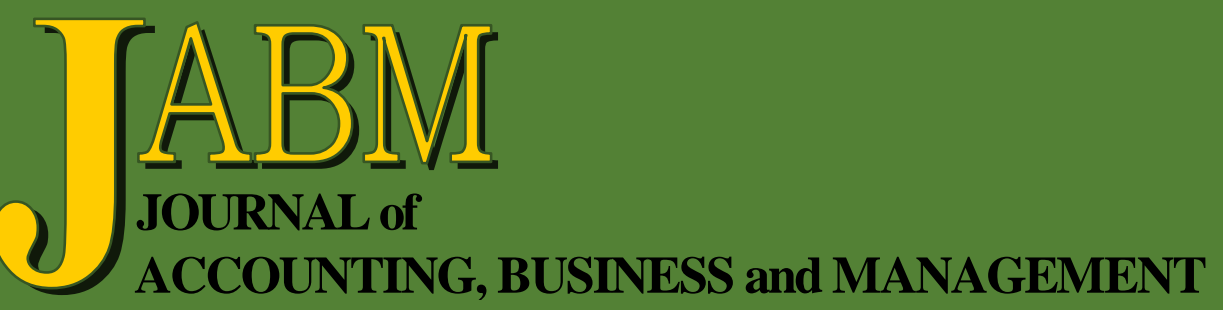

An Analysis of Management Accounting System Development from the Structuration Theory Viewpoint

Anthony Moung Yin Chan, Paul Lo and Kong Ng

Impact of Total Asset Turnover Ratios on Equity Returns: Dynamic Panel Data Analyses

Jeanne-Claire Patin, Matiur Rahman and Muhammad Mustafa

The Impact of Audit Committees on US Nonprofit Organizations'

Governance

Husam Abu-Khadra

Implicit Taxes Amid Race to the Bottom in a Global Tax Game

Igor Semenenko, Junwook Yoo and Parporn Akathaporn

The Adoption of Financial Accounting Standards for Small Medium Enterprises by Muslim Entrepreneurs

Muslichah, Sunarto, Anang Amir Kusnanto, Sri Indrawati and Hariyanto

The Impact of E-Procurement Systems in the Biomedical Industry

A. Seetharaman, Nitin Patwa, Simon Lai Koek Wai and Ahammed Shamir

After-Tax Discounting: A Research Edge

Hongtao Guo

Rules-Based Accounting Standards and SEC Enforcement

Devon Baranek 
Journal of Accounting, Business and Management vol. 27 no. 1 (2020) 42-53

\title{
Implicit Taxes Amid Race to the Bottom in a Global Tax Game
}

\author{
Igor Semenenko* \\ Junwook Yoo ${ }^{\dagger}$ \\ Parporn Akathaporn $\ddagger$
}

\begin{abstract}
Growing tax competition among national governments in the presence of capital mobility distorts equilibrium in the international corporate tax market. This paper is related to the literature that examines impact of international tax policies on corporate accounting statements. Employing international firm-level data, this study revisits the race-to-the-bottom hypothesis and documents that tax exemptions lowering effective tax rates relative to statutory rates increase pre-tax returns. This finding directly contradicts the implicit tax hypothesis documented by Wilkie (1992), who provided empirical evidence on inverse relationship between pre-tax return and tax subsidy. We also find evidences that relative importance of permanent versus timing component depends on the geography and that decline in corporate tax rates reduces impact of tax subsidies on profitability. Our findings suggest that tax subsidies play a different role than in 1968-1985, which was examined by Wilkie (1992). These results are consistent with the race-to-the-bottom hypothesis and income shifting explanation.
\end{abstract}

Keywords: tax subsidy, implicit tax, effective tax rate, firm profitability, incomeshifting, international corporate tax rate.

\section{INTRODUCTION}

Increasing globalization of international economic environment has created a fertile ground for competition among national governments in attempt to lower mobility of factors of production and retain tax residency of corporate legal entities.

A characteristic feature of international tax competition is sharing of a mobile tax base by sovereign states. Countries lowering their tax rates increase tax base at the expense of their peers, who, in response, reduce their taxes, creating a nose diving spiral of corporate taxation. This phenomenon has become known as race-to-thebottom in academic literature and popular media.

Early on, Oates (1972) argues that competition may lead to inefficiently low taxes. Empirical evidence on corporate income tax developments includes several stylized facts, including decrease in statutory and effective tax rates (see Devereux et al., 2002; Abbas et al., 2012). In 2018, average corporate tax rate stood at $24 \%$, down from 49\% in 1985 (Tørsløv et al., 2018, p. 1).

Our study expands the academic literature by breaking down impact of tax subsidies on corporate profitability into permanent and timing components. Briefly, our results are as follows. We find that larger tax subsidies positively impact return on

\footnotetext{
* Acadia University, 15 University Ave, Wolfville, NS, Canada B4P2R6. E-mail: igor.semenenko@acadiau.ca.

$\dagger$ Corresponding author: California State University East Bay, 25800 Carlos Bee Blvd, Hayward, CA, USA 94542. E-mail: junwook.yoo@csueastbay.edu.

‡ Marshall University, 1 John Marshall Dr, Huntington, WV, USA 25755. E-mail: akathaporn@marshall.edu.
} 
equity, suggesting income shifting rather than implicit tax explanation. Second, relative importance of permanent versus timing component depends on the geography. Finally, decline in corporate tax rates reduces impact of tax subsidies on profitability (Sweden is a notable exception).

The organization of the article is as follows. The next section reviews literature on international corporate tax policies and outlines motivation for this study. It is followed by a description of the data, discussion of results, robustness checks and concluding remarks. Appendices provide variables definition and a list of stock exchanges included in this study.

\section{MOTIVATION, METHODOLOGY AND DATA DESCRIPTION}

Ex ante, it is not clear whether tax subsidies should boost corporate profitability ratios. Wilkie (1992) documents inverse relationship between pre-tax returns and tax subsidies in a subsample of 818 US-based firms in 1968-85 and rules in favor of implicit tax hypothesis. In this framework, firms reallocate resources away from the pre-tax optimum established by the private market and toward an equilibrium that yields greater social welfare. The decrease in the pre-tax rate of return is an implicit tax because that part of the return is forgone even if no longer paid as an explicit tax.

In a similar vein, Plümper et al. (2009) argued that fiscal competition under budget rigidities and fairness norms leads to separating equilibria - diverse tax policies even in a population of homogeneous countries.

The alternative explanation is the race-to-the-bottom hypothesis, which predicts convergence of tax policies and decrease in corporate tax rates in an attempt to capture a slice of the internationally mobile tax base by sovereign governments (see Wilson, 1999; Keen \& Konrad, 2013, for a survey of literature on tax competition). It appears that tangible capital mobility has become slightly more correlated with tax rate over the last several decades (Abbas \& Klemm, 2013; Tørsløv et al., 2018).

Interestingly, popular press and a large number of empirical papers have been staunchly on the side of the race-to-the-bottom explanation (Sachs, 2011; Abbas et al., 2012), whereas theory-grounded research often refutes convergence in global tax rates (Plümper et al., 2009). In addition, several other explanations have been forwarded to explain a drop in international corporate tax rates. Grubert and Mutti (1991) and Klassen and Laplante (2012) suggested better tax planning by firms, whereas Houlder (2014) argued for presence of special tax deals or holidays.

Understanding whether implicit taxation affects pre-tax returns is important because it represents real economic cost. Misunderstanding interaction of explicit and implicit taxes may lead to flawed policy recommendations and loss of tax revenue or shrinkage of tax base. This study's contribution is to identify lack of implicit taxation in the current shifting international tax environment.

Several papers have previously examined the effect of different jurisdictional tax rates in a study of implicit taxes. Bryant-Kutcher et al. (2012) examine negative relationship between foreign tax rates and Tobin's $Q$ and document that the tax advantage from lower foreign tax rates is not completely removed by implicit taxes. Markle et al. (2017) focus their analysis on single-country firms and find that lower tax rates are associated with higher investments, which should drive up wages and asset costs, consistent with the implicit tax hypothesis. More recently, Tørsløv et al. (2018) attempted to quantify income shifting effects for multinational firms.

This paper is related to the strand of literature that examines impact of international tax policies on corporate accounting statements. Its research design closely 
follows Wilkie (1992), but our findings suggest that tax subsidies play a different role than in 1968-1985. This result is consistent with the race-to-the-bottom hypothesis and income shifting explanation.

We examine two measures of pre-tax income (PTI): (1) net income to common stockholders including extraordinary items plus minority interest in earnings plus income tax expense less income/(loss) from affiliates; (2) earnings before tax excluding unusual items. The first of these metrics follows step-by-step PTI definition in Wilkie's (1992) paper, thus allowing for direct comparison of our results. Pre-tax income is scaled by stockholders' equity to generate profitability ratios, PTROE (see Appendix A). In specific, PTROE1 is calculated with the metric (1) as in Wilkie (1992); PTROE2 is calculated with (2) earnings before tax excluding unusual items. Both profitability ratios are winsorized at $1 \%$ level to mitigate impact of outliers.

Regression models follow the same specifications as in Wilkie's paper. We examine impact of pre-tax equivalent of tax subsidy on stockholders' equity (PTTSE) on profitability ratios in the whole sample and subsample of firms without net operating losses (see Tables 3-4).

Table 5 breaks up tax subsidy equivalent into permanent and timing components. Models in Table 3-5 follow the same specifications: Models 1-3 examine impact on PTI defined as in Wilkie's paper, and Models 4-6 examine impact on earnings before tax excluding unusual items. Further, Models 2 and 5 add fixed effects, and Models 3 and 6 add firm-level characteristics.

Industry fixed effects control for differentiated impact on firms with different types of assets of changes in corporate taxation. This approach chimes in with finding by Markle et al. (2017) that firms with high levels of intellectual capital are better able to avoid implicit taxes and retain more explicit tax savings. Forty-eight industries are defined as in Fama and French (1997).

Table 1

Effect of Sample Selection Procedures on Sample Size

\begin{tabular}{|c|c|c|}
\hline No. & Procedure & Sample \\
\hline 1. & Publicly traded firms, common stock. & 27,970 \\
\hline 2. & Delete non-exchange listed firms and firms with missing ticker. & $(5,705)$ \\
\hline 3. & Delete off-shore centers and small island states. & $(560)$ \\
\hline 4. & Delete public utilities (SIC codes 4000-4999). & $(1,374)$ \\
\hline 5. & $\begin{array}{l}\text { Delete financial institutions and insurance firms (SIC does 6000- } \\
6999 \text { ). }\end{array}$ & $(2,524)$ \\
\hline 6. & $\begin{array}{l}\text { Delete firms with missing financial statement data in any year } \\
\text { during the } 2010-2017 \text { period. }\end{array}$ & $(11,408)$ \\
\hline 7. & $\begin{array}{l}\text { Delete firms with negative stockholders' equity balances in any } \\
\text { year during the } 2010-2017 \text { period. }\end{array}$ & $(1,207)$ \\
\hline 8. & Total sample. & 5,192 \\
\hline 9. & $\begin{array}{l}\text { Sub-sample of firms with net operating losses in any year during } \\
\text { the } 2010-2017 \text { period. }\end{array}$ & $(3,468)$ \\
\hline 10. & $\begin{array}{l}\text { Sub-sample of firms without net operating losses in any year } \\
\text { during the } 2010-2017 \text { period. }\end{array}$ & 1,724 \\
\hline
\end{tabular}

The dataset includes publicly traded firms listed on major global exchanges. It excludes island states and tax havens, the frontrunners in a global race-to-the-bottom on corporate tax, which host firms that are significantly more profitable than foreign 
firms in non-haven countries (Tørsløv et al., 2018). Table 1 reports step-by-step sample composition.

The main source of data is the S\&P Capital IQ platform, and data on statutory tax rates was procured from KPMG ${ }^{1}$. Table 2 reports means for selected variables on a country-by-country basis and pairwise correlations between average tax rate and averages for key variables of interest.

Table 2

\section{Sample Composition by Country and Variable Means}

The table reports sample composition by country and means for selected variables. Both profitability ratios - PTROE1 calculated with the pre-tax income metric as in Wilkie (1992) and PTROE2 calculated with earnings before tax excluding unusual items - are winsorized at 1\% level.

\begin{tabular}{|c|c|c|c|c|c|c|c|c|c|c|}
\hline (1) & (2) & (3) & (4) & (5) & (6) & (7) & (8) & (9) & (10) & (11) \\
\hline Country & Total & $\begin{array}{c}\text { w/ } \\
\text { NOL }\end{array}$ & $\begin{array}{l}\text { w/o } \\
\text { NOL }\end{array}$ & PTROE1 & PT & $\begin{array}{l}\text { PTTSE, } \\
\text { w/NOL }\end{array}$ & $\begin{array}{c}\text { PTTSE, } \\
\text { w/o NOL }\end{array}$ & E_p & E_t & $\begin{array}{l}\text { Average } \\
\text { Tax Rate }\end{array}$ \\
\hline Australia & 264 & 19 & 245 & 0.040 & 0.081 & 0.013 & 0.011 & 0.009 & 0.002 & $30.00 \%$ \\
\hline Austria & 1 & 0 & 1 & 0.148 & 0.139 & n.a. & 0.038 & 0.047 & -0.009 & $25.00 \%$ \\
\hline Belgium & 48 & 28 & 20 & 0.102 & 0.145 & 0.018 & 0.008 & -0.007 & 0.015 & $33.99 \%$ \\
\hline Brazil & 22 & 6 & 16 & 0.085 & 0.120 & 0.025 & 0.206 & 0.021 & 0.005 & $34.00 \%$ \\
\hline Canada & 271 & 194 & 77 & 0.030 & 0.060 & 0.009 & 0.009 & 0.004 & 0.005 & $27.13 \%$ \\
\hline Chile & 1 & 1 & 0 & 0.247 & 0.259 & -0.011 & -0.011 & -0.022 & 0.011 & $21.13 \%$ \\
\hline China & 1,751 & 1,569 & 182 & 0.092 & 0.098 & 0.004 & 0.005 & 0.007 & -0.002 & $25.00 \%$ \\
\hline Denmark & 1 & 0 & 1 & -0.363 & -0.328 & n.a. & 0.012 & 0.000 & 0.012 & $23.81 \%$ \\
\hline France & 230 & 98 & 132 & 0.093 & 0.140 & 0.004 & 0.006 & 0.005 & 0.000 & $33.33 \%$ \\
\hline Germany & 127 & 100 & 27 & 0.123 & 0.141 & -0.001 & -0.001 & 0.002 & -0.002 & $29.58 \%$ \\
\hline India & 33 & 2 & 31 & 0.263 & 0.263 & 0.019 & 0.019 & 0.021 & -0.002 & $33.84 \%$ \\
\hline Ireland & 15 & 9 & 6 & 0.115 & 0.188 & -0.007 & -0.013 & -0.006 & -0.007 & $12.50 \%$ \\
\hline Israel & 29 & 27 & 2 & 0.003 & 0.032 & 0.011 & 0.010 & 0.000 & -0.005 & $24.94 \%$ \\
\hline Italy & 1 & 1 & 0 & -0.137 & -0.113 & 0.000 & n.a. & n.a. & n.a. & $30.48 \%$ \\
\hline Japan & 12 & 3 & 9 & 0.115 & 0.153 & -0.001 & -0.003 & -0.008 & 0.005 & $36.08 \%$ \\
\hline Mexico & 3 & 3 & 0 & 0.119 & 0.127 & 0.005 & 0.005 & 0.007 & -0.001 & $30.00 \%$ \\
\hline Netherlands & 55 & 46 & 9 & 0.099 & 0.144 & -0.002 & 0.000 & 0.004 & -0.004 & $25.06 \%$ \\
\hline New Zealand & 1 & 0 & 1 & -0.213 & -0.212 & n.a. & 0.000 & 0.000 & 0.000 & $28.25 \%$ \\
\hline Portugal & 1 & 0 & 1 & 0.080 & 0.092 & n.a. & -0.013 & 0.002 & -0.015 & $23.25 \%$ \\
\hline Russia & 7 & 5 & 2 & 0.230 & 0.258 & -0.002 & -0.003 & -0.007 & 0.004 & $20.00 \%$ \\
\hline South Korea & 4 & 2 & 2 & 0.077 & 0.098 & -0.009 & -0.005 & 0.000 & -0.005 & $23.65 \%$ \\
\hline Spain & 31 & 13 & 18 & 0.152 & 0.180 & 0.004 & 0.002 & 0.008 & -0.006 & $28.50 \%$ \\
\hline Sweden & 156 & 74 & 82 & 0.129 & 0.145 & 0.001 & 0.004 & 0.002 & 0.002 & $23.61 \%$ \\
\hline Switzerland & 112 & 81 & 31 & 0.115 & 0.136 & -0.011 & -0.010 & -0.007 & -0.003 & $18.08 \%$ \\
\hline Taiwan & 481 & 322 & 159 & 0.090 & 0.100 & -0.002 & -0.003 & -0.005 & 0.002 & $17.00 \%$ \\
\hline $\begin{array}{l}\text { United } \\
\text { Kingdom }\end{array}$ & 217 & 102 & 115 & 0.145 & 0.193 & -0.007 & -0.004 & -0.004 & 0.000 & $22.63 \%$ \\
\hline United States & 1,318 & 763 & 555 & 0.110 & 0.145 & 0.033 & 0.033 & 0.031 & 0.002 & $40.00 \%$ \\
\hline Total & 5,192 & 3,468 & 1,724 & 0.096 & 0.119 & 0.009 & 0.01095 & 0.01080 & 0.00015 & \\
\hline Correlatio & with a & verag & $a x$ & -0.033 & -0.037 & 0.74 & 0.39 & 0.44 & 0.26 & 1.00 \\
\hline
\end{tabular}

Notably, a large number of countries have negative average timing component of tax subsidy (column 10), but this result does not contradict Wilkie (1992), who reports

\footnotetext{
${ }^{1}$ https://home.kpmg/xx/en/home/services/tax/tax-tools-and-resources/tax-rates-online/ corporate-tax-rates-table.html accessed on March 3, 2019.
} 
negative mean and median for one of the tax subsidy components in three out of eighteen years in 1968-1985. Further, medians for many of the countries included in Table 2 are positive or equal to zero.

Preliminary analysis suggests that differential impact of tax subsidies is directly related to statutory tax rates. Pairwise correlation between country-average pre-tax equivalent of tax subsidy on stockholders' equity (PTTSE) and statutory tax rates is 0.39 in a subsample of firms without net operating losses and 0.74 for firms with NOLs.

\section{EMPIRICAL FINDINGS}

Table 3 shows our key empirical results - tax subsidies have a positive and statistically significant effect on corporate profitability. In Models 4-6 which employ PTROE2 calculated with earnings before tax excluding unusual items as dependent variable, pre-tax equivalent of tax subsidy on stockholders' equity (PTTSE) is borderline insignificant in two specifications out of three, but $\mathrm{p}$-value on beta coefficient is just 0.11 , a fraction above conventionally significant levels. Further, PTTSE attains significance in the most complete specification (Model 6). Net operating losses categorical variable attains statistical significance and predicted sign in all specifications, whereas interaction variable is positive and significant in line with expectations.

\section{Table 3}

\section{Results of Regressions of Pre-Tax ROE on Tax Subsidy Variables}

The table reports regression model results. The dependent variables are profitability ratios: PTROE1 calculated with the pre-tax income metric as in Wilkie (1992) in columns 1-3 and PTROE2 calculated with earnings before tax excluding unusual items in columns 4-6. The standard error is corrected for clustering following Petersen (2009). *, **, and *** indicate a pvalue of $10 \%, 5 \%$, and $1 \%$, respectively. Panel A reports results for the whole sample; panels B-D report selected output for the United States, China and the rest of the sample, respectively.

\begin{tabular}{lcccccc}
\hline & $\mathbf{( 1 )}$ & $\mathbf{( 2 )}$ & $\mathbf{( 3 )}$ & $\mathbf{( 4 )}$ & $\mathbf{( 5 )}$ & $\mathbf{( 6 )}$ \\
\hline Panel A: Whole & & & & & & \\
\hline Intercept & $0.109^{* * *}$ & $0.131^{* * *}$ & $-0.041^{* *}$ & $0.148^{* * *}$ & $0.175^{* * *}$ & -0.001 \\
& 22.90 & 7.32 & -1.99 & 38.17 & 8.87 & -0.05 \\
NOL & $-0.033^{* * *}$ & $-0.037^{* * *}$ & $-0.043^{* * *}$ & $-0.041^{* * *}$ & $-0.031^{* * *}$ & $-0.036^{* * *}$ \\
& -5.99 & -6.62 & -7.53 & -9.29 & -6.81 & -8.26 \\
PTTSE & $0.880^{* * *}$ & $0.909^{* * *}$ & $0.835^{* * *}$ & 0.019 & 0.018 & $0.014^{*}$ \\
& 5.21 & 5.09 & 4.18 & 1.62 & 1.63 & 1.75 \\
PTTSE*NOL & -0.114 & -0.106 & -0.072 & $0.297^{* * *}$ & $0.289^{* * *}$ & $0.378^{* * *}$ \\
& -0.58 & 0.206 & -0.32 & 3.72 & 3.76 & 6.11 \\
Log_assets & & & $0.033^{* * *}$ & & & $0.030^{* * *}$ \\
& & & 0.002 & & & $-0.134^{* * *}$ \\
Leverage & & & $-0.221^{* * *}$ & & & -10.69 \\
& & & -16.03 & & & $0.0004^{*}$ \\
Growth & & & $0.0003^{*}$ & & & 1.78 \\
& & & & & & \\
Fixed Effects: & No & Yes & Yes & No & Yes & Yes \\
$\quad$ Year Effects & No & Yes & Yes & No & Yes & Yes \\
$\quad$ Industry & No & Yes & Yes & No & Yes & Yes \\
$\quad$ Country Effects & No & & & & & \\
Clustered Error Term: & & Yes & Yes & Yes & Yes & Yes \\
$\quad$ Company & Y1,512 & 41,512 & 36,076 & 41,512 & 41,512 & 36,076 \\
$\quad$ N & 0.056 & 0.119 & 0.174 & 0.096 & 0.167 & 0.262 \\
$\quad$ R-squared & & & &
\end{tabular}


To be continued Panel B from Table 3.

\begin{tabular}{lcccccc}
\hline Panel B: United States & \multicolumn{7}{c}{} \\
\hline PTTSE & $1.160^{* * *}$ & $1.163^{* * *}$ & $1.059^{* * *}$ & $1.100^{* * *}$ & $1.069^{* * *}$ & $1.077^{* * *}$ \\
& 6.99 & 7.25 & 6.35 & 9.52 & 9.66 & 11.22 \\
R-squared & 0.127 & 0.183 & 0.261 & 0.237 & 0.293 & 0.422 \\
\hline Panel C: China & & & & & $0.350^{* *}$ \\
\hline PTTSE & $1.877^{* * *}$ & $1.860^{* * *}$ & $1.918^{* * *}$ & $0.428^{* *}$ & $0.409^{* * *}$ & 2.06 \\
& 5.49 & 6.13 & 6.30 & 2.22 & 2.21 & 0.272 \\
\hline R-squared & 0.069 & 0.159 & 0.173 & 0.141 & 0.228 & $0.010^{* *}$ \\
\hline Panel D: United States and China Excluded & & & & 2.20 \\
\hline PTTSE & $0.513^{* *}$ & $0.573^{* *}$ & $0.509^{*}$ & $0.014^{* *}$ & $0.013^{* *}$ & 0.243 \\
\hline
\end{tabular}

Table 4 puts tax subsidy variable (PTTSE) to test in a subsample of firms without net operating losses. Results are mirror-image of output reported in Table 3 for the whole sample - PTTSE variable is significant in four models out of six and borderline insignificant in two restricted models (4 and 5) which employ PTROE2 calculated with earnings before tax excluding unusual items as dependent variable. Panels B-D in each table report selected output for three subsamples of roughly equal size - United States, China and other firms. Tax subsidy variable attains different slopes in each subsample, but results for the whole sample are clearly not driven by corporate performance in any particular geography.

\section{Table 4}

\section{Results of Regressions in a Subsample of Firms without Net Operating Losses}

The table reports regression model results in a subsample of firms without net operating losses. The dependent variables are profitability ratios: PTROE1 calculated with the pre-tax income metric as in Wilkie (1992) in columns 1-3 and PTROE2 calculated with earnings before tax excluding unusual items in columns 4-6. The standard error is corrected for clustering following Petersen (2009). *, **, and *** indicate a p-value of $10 \%, 5 \%$, and $1 \%$, respectively. Panel A reports results for the whole sample; panels B-D report selected output for the United States, China and the rest of the sample, respectively.

\begin{tabular}{lcccccc}
\hline & $\mathbf{( 1 )}$ & $\mathbf{( 2 )}$ & $\mathbf{( 3 )}$ & $\mathbf{( 4 )}$ & $\mathbf{( 5 )}$ & $\mathbf{( 6 )}$ \\
\hline Panel A: Whole sample & & & & & & \\
\hline Intercept & $0.109^{* * *}$ & $0.156^{* * *}$ & 0.021 & $0.148^{* * *}$ & $0.204^{* * *}$ & 0.037 \\
& 22.89 & 5.06 & 0.62 & 38.16 & 6.83 & 1.17 \\
PTTSE & $0.88^{* * *}$ & $0.90^{* * *}$ & $0.837^{* * *}$ & 0.019 & 0.017 & $0.013^{*}$ \\
& 5.21 & 4.87 & 4.04 & 1.62 & 1.62 & 1.73 \\
Log_Assets & & & $0.027^{* * *}$ & & & $0.029^{* * *}$ \\
& & & 10.78 & & & 12.41 \\
Leverage & & $-0.194^{* * *}$ & & & $-0.123^{* * *}$ \\
& & & -7.43 & & & -4.90 \\
Growth & & & $0.0002^{* * *}$ & & & $0.0002^{* * *}$ \\
& & & 2.61 & & & -4.90 \\
Fixed Effects: & No & Yes & Yes & No & Yes & Yes \\
$\quad$ Year Effects & No & Yes & Yes & No & Yes & Yes \\
$\quad$ Industry Effects & No & Yes & Yes & No & Yes & Yes \\
$\quad$ Country Effects & & & & & & Yes \\
Clustered Error Term: & Yes & Yes & Yes & Yes & Yes & Yes \\
$\quad$ Nompany & 13,774 & 13,774 & 11,936 & 13,774 & 13,774 & 11,936 \\
$\quad$ R-squared & 0.053 & 0.140 & 0.178 & 0.009 & 0.115 & 0.174 \\
\hline
\end{tabular}


To be continued Panel C from Table 4.

\begin{tabular}{|c|c|c|c|c|c|c|}
\hline \multicolumn{7}{|c|}{ Panel B: United States } \\
\hline PTTSE & $\begin{array}{c}1.160^{* * *} \\
6.99\end{array}$ & $\begin{array}{c}1.199 * * * \\
7.87\end{array}$ & $\begin{array}{c}1.123^{* * *} \\
7.17\end{array}$ & $\begin{array}{c}1.097^{* * *} \\
9.51\end{array}$ & $\begin{array}{c}1.087^{* * *} \\
9.99\end{array}$ & $\begin{array}{c}1.127^{* * *} \\
11.86\end{array}$ \\
\hline R-squared & 0.149 & 0.217 & 0.277 & 0.381 & 0.444 & 0.497 \\
\hline \multicolumn{7}{|c|}{ Panel C: China } \\
\hline PTTSE & $\begin{array}{c}1.877 \text { *** } \\
5.47\end{array}$ & $\begin{array}{c}2.085^{* * *} \\
6.89\end{array}$ & $\begin{array}{c}2.110^{* * * *} \\
6.80\end{array}$ & $\begin{array}{c}0.428^{* *} \\
2.21\end{array}$ & $\begin{array}{c}0.404^{* *} \\
2.21\end{array}$ & $\begin{array}{c}0.365^{* *} \\
2.18\end{array}$ \\
\hline R-squared & 0.159 & 0.349 & 0.341 & 0.124 & 0.320 & 0.365 \\
\hline \multicolumn{7}{|c|}{ Panel D: United States and China Excluded } \\
\hline PTTSE & $\begin{array}{c}0.513^{* *} \\
2.17\end{array}$ & $\begin{array}{c}0.577 * * \\
2.17\end{array}$ & $\begin{array}{c}0.511^{*} \\
1.76\end{array}$ & $\begin{array}{c}0.014^{* *} \\
1.96\end{array}$ & $\begin{array}{c}0.013^{* *} \\
1.97\end{array}$ & $\begin{array}{c}0.010^{* *} \\
0.005\end{array}$ \\
\hline R-squared & 0.012 & 0.125 & 0.159 & 0.008 & 0.139 & 0.186 \\
\hline
\end{tabular}

On aggregate, it appears that larger tax subsidies boost corporate profitability. The conclusion is in stark contrast with Wilkie (1992), who reported negative coefficients on tax subsidies in a sample of the U.S. firms. We conclude that the global market has moved from separating equilibria toward a more integrated market, tax harmonization and competition for international tax base. This finding falls in line with Hines and Rice (1994) and Carnaghan et al. (2014), who predict that firms will report more taxable income in countries that have lower corporate tax rates.

\section{Table 5}

\section{Results of Regressions on Permanent and Timing Components of Pre-Tax Equivalent of} Tax Subsidy

The table reports regression model results of firm profitability on permanent and timing components of pre-tax equivalent of tax subsidy in a subsample of firms without net operating losses. The dependent variables are profitability ratios: PTROE1 calculated with the pre-tax income metric as in Wilkie (1992) in columns 1-3 and PTROE2 calculated with earnings before tax excluding unusual items in columns 4-6. The standard error is corrected for clustering following Petersen (2009). ${ }^{*}, * *$, and $* * *$ indicate a p-value of $10 \%, 5 \%$, and $1 \%$, respectively. Panel A reports results for the whole sample; panels B-D report selected output for the United States, China and the rest of the sample, respectively.

\begin{tabular}{|c|c|c|c|c|c|c|}
\hline & (1) & (2) & (3) & (4) & (5) & (6) \\
\hline \multicolumn{7}{|c|}{ Panel A: Whole sample } \\
\hline \multirow[t]{2}{*}{ Intercept } & $0.109^{* * *}$ & $0.156^{* * * *}$ & 0.021 & $0.139 * * *$ & $0.191^{* * *}$ & 0.029 \\
\hline & 24.98 & 5.11 & 0.63 & 34.08 & 5.65 & 0.81 \\
\hline \multirow[t]{2}{*}{ PTTSE_p } & $0.893^{* * *}$ & $0.914 * * *$ & $0.882^{* * *}$ & $0.565^{* * *}$ & $0.555^{* * *}$ & $0.497^{* * *}$ \\
\hline & 8.05 & 7.88 & 8.04 & 5.98 & 5.85 & 5.33 \\
\hline \multirow[t]{2}{*}{ PTTSE_t } & $1.088^{* * *}$ & $1.126 * * *$ & $1.145^{* * *}$ & $0.694 * * *$ & $0.696 * * *$ & $0.663^{* * *}$ \\
\hline & 8.53 & 8.82 & 8.93 & 6.46 & 6.65 & 6.02 \\
\hline \multirow[t]{2}{*}{ Log_assets } & & & $0.027 * * *$ & & & $0.029 * * *$ \\
\hline & & & 10.84 & & & 12.44 \\
\hline \multirow[t]{2}{*}{ Leverage } & & & $-0.194 * * *$ & & & $-0.123^{* * *}$ \\
\hline & & & -7.49 & & & -5.01 \\
\hline \multirow[t]{2}{*}{ Growth } & & & $0.0002^{* * *}$ & & & $0.0002^{* * *}$ \\
\hline & & & 2.65 & & & 3.05 \\
\hline \multicolumn{7}{|l|}{ Fixed Effects: } \\
\hline Year Effects & No & Yes & Yes & No & Yes & Yes \\
\hline Industry Effects & No & Yes & Yes & No & Yes & Yes \\
\hline Country Effects & No & Yes & Yes & No & Yes & Yes \\
\hline \multicolumn{7}{|c|}{ Clustered Error Term: } \\
\hline Company & Yes & Yes & Yes & Yes & Yes & Yes \\
\hline $\mathbf{N}$ & 13,774 & 13,774 & 11,936 & 13,774 & 13,774 & 11,936 \\
\hline R-squared & 0.057 & 0.144 & 0.186 & 0.029 & 0.134 & 0.190 \\
\hline
\end{tabular}


To be continued Panel B from Table 5.

\begin{tabular}{|c|c|c|c|c|c|c|}
\hline \multicolumn{7}{|c|}{ Panel B: United States } \\
\hline \multirow{2}{*}{$\overline{\text { PTTSE_p }}$} & $1.285^{* * *}$ & $1.331 * * *$ & $1.223^{* * *}$ & $1.040^{* * *}$ & $1.071 * * *$ & $0.906^{* * *}$ \\
\hline & 8.21 & 9.36 & 8.14 & 8.74 & 9.50 & 7.79 \\
\hline \multirow[t]{2}{*}{ PTTSE_t } & $0.959 * * *$ & $0.989 * * *$ & $0.965^{* * *}$ & $0.734^{* * *}$ & $0.748^{* * *}$ & $0.665^{* * *}$ \\
\hline & 0.174 & 6.14 & 5.71 & 5.09 & 5.35 & 4.52 \\
\hline R-squared & 0.158 & 0.227 & 0.282 & 0.127 & 0.212 & 0.284 \\
\hline \multicolumn{7}{|c|}{ Panel C: China } \\
\hline \multirow[t]{2}{*}{ PTTSE_p } & $2.172 * * *$ & $2.393^{* * *}$ & $2.259 * * *$ & $1.254^{* *}$ & $1.496^{* * *}$ & $1.564^{* * *}$ \\
\hline & 6.37 & 7.53 & 6.74 & 2.51 & 3.31 & 3.16 \\
\hline \multirow[t]{2}{*}{ PTTSE_t } & $-2.806^{* * *}$ & $-2.461 * * *$ & $-1.559 * *$ & $-4.146^{* * *}$ & $-3.736 * * *$ & $-2.558^{* * *}$ \\
\hline & 0.906 & -3.23 & 2.38 & -3.63 & -4.34 & -3.03 \\
\hline R-squared & 0.211 & 0.397 & 0.367 & 0.105 & 0.322 & 0.347 \\
\hline \multicolumn{7}{|c|}{ Panel D: United States and China Excluded } \\
\hline \multirow[t]{2}{*}{ P'T'TSE_p } & $0.662^{* * *}$ & $0.754 * * *$ & $0.780^{* * *}$ & 0.161 & $0.237^{*}$ & 0.226 \\
\hline & 5.84 & 6.26 & 0.115 & 1.32 & 1.92 & 1.62 \\
\hline \multirow[t]{2}{*}{ PTTSE_t } & $0.950 * * *$ & $1.088^{* * *}$ & $1.167 * * *$ & $0.296^{*}$ & $0.412^{* *}$ & $0.417^{* *}$ \\
\hline & 6.18 & 6.51 & 7.85 & 1.87 & 2.55 & 2.31 \\
\hline R-squared & 0.02 & 0.136 & 0.174 & 0.003 & 0.138 & 0.186 \\
\hline
\end{tabular}

Table 5 breaks up tax subsidy into permanent and timing components. The only result out of line with the rest of the sample is consistently negative relationship between timing component of tax subsidy (PTTSE_t) and firm profitability (PTROE1 and PTROE2) in China. Outside measurement error and possible market frictions, we can't suggest an explanation for this result.

\section{Table 6}

Results of Regressions for Four Countries, in Which Corporate Tax Rates Decreased The table reports regression model results for four countries, in which tax rates decreased in 2010-2017 and number of firms without net operating losses is larger than 10. The dependent variable is PTROE1 which is calculated with the pre-tax income metric as in Wilkie (1992). The standard error is corrected for clustering following Petersen (2009). *, **, and *** indicate a pvalue of $10 \%, 5 \%$, and $1 \%$, respectively. Panels A-D reports results for Canada, Spain, Sweden and United Kingdom, respectively.

\begin{tabular}{|c|c|c|c|c|c|c|c|c|}
\hline & 2010 & 2011 & 2012 & 2013 & 2014 & 2015 & 2016 & 2017 \\
\hline \multicolumn{9}{|c|}{ Panel A: Canada } \\
\hline Tax rates & $31 \%$ & $28 \%$ & $26 \%$ & $26 \%$ & $26.5 \%$ & $26.5 \%$ & $26.5 \%$ & $26.5 \%$ \\
\hline PTTSE_p & $1.877 * * *$ & $1.030^{* * *}$ & $1.358^{*}$ & 0.412 & $-2.335^{* *}$ & -1.221 & 0.382 & 0.626 \\
\hline PTTSE_t & $1.581 * * *$ & $2.113^{* * *}$ & 1.006 & 0.621 & 1.150 & -0.190 & 0.428 & -0.551 \\
\hline R-squared & 0.333 & 0.179 & 0.057 & 0.006 & 0.075 & 0.010 & 0.003 & 0.016 \\
\hline \multicolumn{9}{|c|}{ Panel B: Spain } \\
\hline Tax rates & $30 \%$ & $30 \%$ & $30 \%$ & $30 \%$ & $30 \%$ & $28 \%$ & $25 \%$ & $25 \%$ \\
\hline PTTSE_p & -3.708 & -1.368 & 1.214 & -3.783 & -2.035 & $-4.864 * * *$ & $-4.867 * * *$ & $-3.416 * *$ \\
\hline PTTSE_t & $-2.004 * * *$ & -0.388 & 0.104 & -1.459 & -1.760 & -0.882 & -2.910 & -0.500 \\
\hline R-squared & 0.416 & 0.058 & 0.031 & 0.178 & 0.118 & 0.440 & 0.265 & 0.438 \\
\hline
\end{tabular}


To be continued Panel C from Table 6.

\begin{tabular}{|c|c|c|c|c|c|c|c|c|}
\hline \multicolumn{9}{|c|}{ Panel C: Sweden } \\
\hline Tax rates & $26.3 \%$ & $26.3 \%$ & $26.3 \%$ & $22 \%$ & $22 \%$ & $22 \%$ & $22 \%$ & $22 \%$ \\
\hline PTTSE_p & 0.768 & $1.054 * * *$ & 1.015 & $1.620^{* *}$ & $2.204 * * *$ & $1.626^{* * *}$ & $1.893^{* * *}$ & $2.078^{* * *}$ \\
\hline PTTSE_t & 0.589 & $1.124^{* *}$ & $1.739 *$ & 0.806 & $2.493^{* * *}$ & $2.445^{* * *}$ & $2.520 * * *$ & $2.068^{* * *}$ \\
\hline R-squared & 0.007 & 0.069 & 0.020 & 0.042 & 0.070 & 0.101 & 0.118 & 0.103 \\
\hline \multicolumn{9}{|c|}{ Panel D: United Kingdom } \\
\hline$\overline{\text { Tax rates }}$ & $28 \%$ & $26 \%$ & $24 \%$ & $23 \%$ & $21 \%$ & $20 \%$ & $20 \%$ & $19 \%$ \\
\hline PTTSE_p & $1.446^{* * *}$ & 1.216 & $-2.231 * *$ & -0.925 & $-1.765^{*}$ & $-2.771 * *$ & -1.666 & 0.641 \\
\hline PTTSE_t & 1.104 & 0.293 & 1.025 & -0.022 & -0.759 & -1.171 & -1.394 & 0.513 \\
\hline R-squared & 0.074 & 0.018 & 0.073 & 0.012 & 0.036 & 0.054 & 0.012 & 0.003 \\
\hline
\end{tabular}

Table 6 reports beta coefficients on permanent and timing components of tax subsidies for four countries with more than ten firms without net operating losses, in which tax rates decreased ${ }^{2}$. Tørsløv et al. (2018) document that enforcement activities of tax authorities focus on transfer price corrections between high-tax countries. Following that logic, a drop in statutory tax rates should impact sensitivities between tax subsidies and profitability metrics.

Results in Table 6, while extremely volatile, suggest that sensitivities do change. One notable exception is Sweden, in which decline in tax rates was followed by increase in partial correlations between both components of tax subsidies and return-on-equity. It is not clear why beta coefficients on tax subsidies in Sweden increase in the wake of declines in corporate tax rates. One possible explanation is sample composition, which could comprise a larger number of domestic firms, which suffer more implicit tax than multinational companies (Chyz et al., 2015).

We conclude that tax subsidies have a positive impact on corporate profitability. Our results speak strongly in favor of income shifting by corporations and growing integration of global capital markets.

\section{CONCLUDING REMARKS}

This paper has conducted empirical tests of the implicit tax hypothesis in a sample of firms listed on major international exchanges. Results suggest movement of the global market from separating toward integrated equilibria and support income shifting by corporate entities.

Contrary to Wilkie (1992), this paper finds that pre-tax return on equity is increasing in tax subsidies, consistent with the race-to-the-bottom hypothesis of income tax convergence around the globe. It contributes to a growing body of literature on income shifting by multinational corporations and provides support to the race-to-thebottom hypothesis. Even though radical predictions of zero tax rate equilibrium have not materialized yet, international tax rates are clearly in a nosedive spin, and corporations exercise bargaining power to negotiate more favorable tax regimes.

The largest sensitivities to tax subsidies are documented in the United States, which had the largest statutory tax rate and one of the lowest effective rates of all countries included in our sample. From that standpoint, Donald Trump's tax reform that reduces headline corporate tax rate from $35 \%$ to $21 \%$ along with a lower repatriation rate for foreign income is nothing more than an attempt to reconcile rules

2 Tax rates increased in Chile and decreased in Portugal, Denmark and Japan, but sample sizes in these countries are small, so the analysis in Table 6 focuses on subsamples with at least ten firms without net operating losses. 
with existing order of things - the U.S. government has long ago recognized a widening gap between statutory and effective tax rates (U.S. Government Accountability Office, 2013).

Results obtained in this paper are important for public finance economists and decision makers. They contribute to a growing literature on international tax policies and fiscal adjustments.

\section{REFERENCE}

Abbas, A. S. M., \& Klemm, A. (2013). A partial race to the bottom: Corporate tax developments in emerging and developing economies. International Tax \& Public Finance, 20(4), 596-617.

Abbas, S. M. A., Klemm, A., Bedi, S., \& Park, J. (2012, January). A partial race to the bottom: Corporate tax developments in emerging and developing economies (WP/12/28). International Monetary Fund (IMF) Working Paper 12/28.

Bryant-Kutcher, L. A., Guenther, D. A., \& Jackson, M. (2012). How do cross-country differences in corporate tax rates affect firm value? The Journal of the American Taxation Association, 34(2), 1-17.

Carnaghan, C., Kenneth, K. J., \& Laplante, S. K. (2014). A model of multinational income shifting and an application to tax planning with e-commerce. The Journal of the American Taxation Association, 36(2), 27-53.

Chyz, J. A., Luna, L., \& Smith, H. (2015, September). Implicit taxes of U.S. domestic and multinational firms over the past quarter-century (Working Paper). Knoxville: The University of Tennessee, Department of Accounting \& Information Management.

Devereux, M. P., Griffith, R., Klemm, A., Thum, M., \& Ottaviani, M. (2002, October). Corporate income tax reforms and international tax competition. Economic Policy, 17(35), 449-495.

Fama, E. F., \& French, K. R. (1997, February). Industry costs of equity. Journal of Financial Economics, 43(2), 153-193.

Grubert, H., \& Mutti, J. (1991, May). Taxes, tariffs and transfer pricing in multinational corporate decision making. The Review of Economics \& Statistics, 73(2), 285-293.

Hines, J. R., \& Rice, E. M. (1994). Fiscal paradise: Foreign tax havens and American business. The Quarterly Journal of Economics, 109(1), 149-182.

Houlder, V. (2014, November 6). Leak reveals scale of corporate tax deals with Luxembourg. The Financial Times.

Keen, M., \& Konrad, K. (2013). The theory of international tax competition and coordination. In Alan, J. A. (Eds.), Handbook of Public Economics (5 ${ }^{\text {th }}$, pp. 257-328). Amsterdam: Elsevier.

Klassen, K. J., \& Laplante, S. K. (2012). Are U.S. multinational corporations becoming more aggressive income shifters? Journal of Accounting Research, 50(5), 1245-1285.

Markle, K. S., Mills, L., \& Williams, B. (2017, June). Income shifting incentives and implicit taxes (Working Paper). University of Iowa, USA.

Oates, W. E. (1972). Fiscal federalism. New York: Harcourt Brace Jovanovich.

Petersen, M. A. (2009). Estimating standard errors in finance panel data sets: Comparing approaches. The Review of Financial Studies, 22(1), 435-480.

Plümper, T., Troeger, V. E., \& Winner, H. (2009, September). Why is there no race to the bottom in capital taxation? International Studies Quarterly, 53(3), 761-786.

Sachs, J. (2011, March 28). Stop this race to the bottom on corporate tax. The Financial Times. 
Tørsløv, T. R., Wier, L. S., \& Zucman, G. (2018, June). The missing profits of nations (Working Paper 24701). Massachusetts Avenue Cambridge, MA 02138: National Bureau of Economic Research.

U.S. Government Accountability Office. (2013, May 30). Corporate income tax: Effective tax rates can differ significantly from the statutory rate (Report to Congressional Requesters). GAO-13-520.

Wilkie, P. J. (1992). Empirical evidence of implicit taxes in the corporate sector. The Journal of the American Taxation Association, 14(1), 97-116.

Wilson, J. D. (1999). Theories of tax competition. National Tax Journal, 52(2), 269-304.

\section{Appendix A \\ Variables Description}

The appendix reports variable names, their descriptions and matching Capital IQ variables

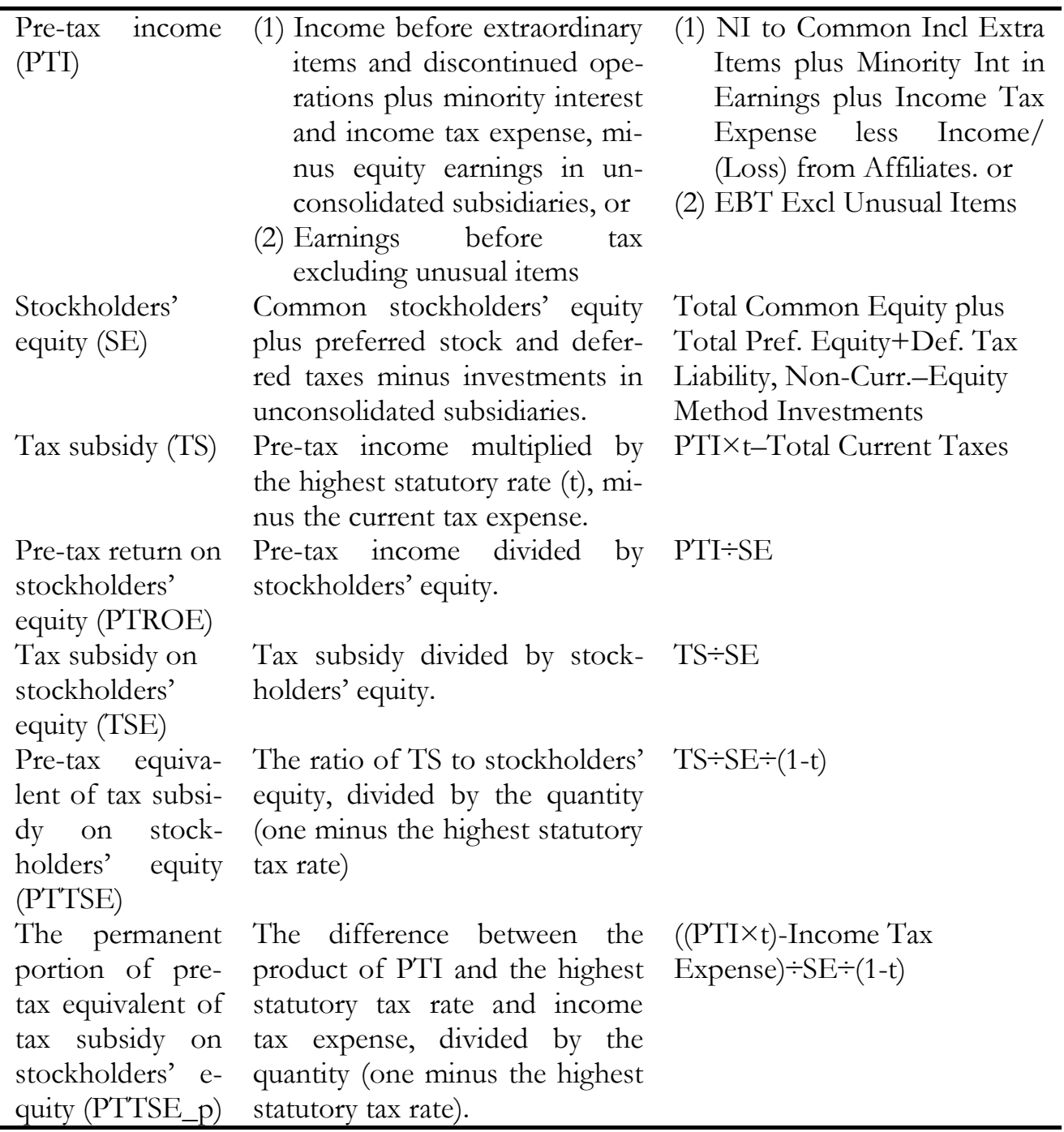


To be continued Appendix A.

\begin{tabular}{|c|c|c|}
\hline $\begin{array}{l}\text { The timing por- } \\
\text { tion of pre-tax } \\
\text { equivalent of tax } \\
\text { subsidy on } \\
\text { stockholders' e- } \\
\text { quity (PTTSE_t) }\end{array}$ & $\begin{array}{l}\text { The difference between income } \\
\text { tax expense and the current } \\
\text { portion of that expense, divided } \\
\text { by the quantity (one minus the } \\
\text { highest statutory tax rate). }\end{array}$ & $\begin{array}{l}\text { [Income Tax Expense- } \\
\text { (Income Tax Expense-Total } \\
\text { Deferred Taxes)] } \div \mathrm{SE} \div(1-\mathrm{t})\end{array}$ \\
\hline $\begin{array}{l}\text { Net Operating } \\
\text { Losses dummy }\end{array}$ & $\begin{array}{l}\text { Categorical variable set to one if } \\
\text { current tax expense is negative } \\
\text { in any year }\end{array}$ & $\begin{array}{l}\text { Total NOL C/F non-zero in } \\
\text { any year in 2010-2017 }\end{array}$ \\
\hline
\end{tabular}

Appendix B

List of Exchanges

The appendix reports list of exchanges and trading floors included in the study

Australia and New Zealand

Australian Securities Exchange (ASX)

\section{Latin America}

Bolsa de Valores de Sao Paulo (BOVESPA)

\section{Europe}

Bolsas y Mercados Espanoles (BME)

Deutsche Boerse AG (DB)

Euronext Amsterdam (ENXTAM)

Euronext Brussels (ENXTBR)

Euronext Paris (ENXTPA)

London Stock Exchange (LSE)

OMX Nordic Exchange Stockholm (OM)

SIX Swiss Exchange (SWX)

Asia

Korea Stock Exchange (KOSE)

Mumbai Stock Exchange (BSE)

National Stock Exchange of India (NSEI)

Shanghai Stock Exchange (SHSE)

Shenzhen Stock Exchange (SZSE)

Taiwan Stock Exchange (TSEC)

The Tokyo Stock Exchange (TSE)

\section{Americas}

New York Stock Exchange (NYSE)

NYSE MKT LLC (AMEX)

Nasdaq Capital Market (NasdaqCM)

Nasdaq Global Market (NasdaqGM)

Nasdaq Global Select (NasdaqGS)

The Toronto Stock Exchange (TSX) 